\title{
Diagnosis, clinical assessment of HIV infection in a pregnant woman and legal aspects of HIV infection
}

\author{
Czesław Żaba', Maciej Osiński² \\ 1Department of Forensic Medicine, Poznan University of Medical Sciences, Poland \\ Head: Czesław Żaba MD, PhD \\ 2Department of Dermatology, Poznan University of Medical Sciences, Poland \\ Head: Prof. Wojciech Silny MD, PhD
}

Postep Derm Alergol 2012; XXIX, 4: 299-307

DOI: $10.5114 /$ pdia.2012.30471

\begin{abstract}
HIV infection is diagnosed using serological tests (detection of HIV1/2-specific antibodies) and tests based on molecular biology techniques (detection of viral nucleic acids: HIV RNA, HIV DNA). Currently, infection with HIV mediated by blood-derived preparations is practically impossible. HIV-specific antibodies pass through placenta to foetal blood, where they may persist till $18^{\text {th }}$ month of life and, therefore, serological tests in children below this age may be falsely positive, which makes establishing a correct diagnosis more difficult. In Poland, only $10 \%$ of pregnant women undergo tests aimed to detect infection with HIV while in some Western countries such tests are performed in as many as $98 \%$ of pregnant women. During pregnancy in a HIV(+) woman, HIV blood load and number of Th CD4+ lymphocytes should be monitored. In Poland, compulsory tests for presence of HIV infection are performed in persons suspected of HIV infection/AIDS; newborns and infants, pregnant women, carriers and individuals in contact with the infected material.
\end{abstract}

Key words: human immunodeficiency virus, serodiagnosis of AIDS, diagnosis of HIV infection/AIDS, HIV infection, law.

\section{Diagnosis}

Diagnosis of HIV infections, which is of interest for several branches of medicine, includes tests linked to screening studies (manifesting high sensitivity), used, e.g. in transfusiology and studies of a high specificity, inseparably linked to the clinic of HIV infection/AIDS and branches such as infectious diseases or venereology.

Currently, infection with blood-derived preparations is practically impossible [1]. Screening tests targeted at HIV represent a routine procedure, used to estimate suitability of a given blood donation for transfusion. They include serological tests aimed at detection of HIV-1/2specific antibodies and tests based on molecular biology techniques, aimed to detect HIV RNA [2]. In order to diagnose HIV infection two serum samples should be isolated from a single blood drawing in a given patient. Subsequently, screening tests are conducted, including EIA (enzyme immunoassay). Negative results of EIA are not further verified. The exception involves the situation in which a test can be suspected to be performed within the so-called serological window or during the period of recent infection, when antibodies have not been produced yet and, therefore, the serological tests give falsely negative results. In the latter case, the serological tests should be repeated after 2 weeks and tests of a higher sensitivity should be taken into account (e.g. tests for presence of viral nucleic acids, HIV DNA, HIV RNA). A positive result of EIA in a single sample requires confirmation using the other sample. In the case of contradictory results, the screening test should be repeated and when both samples yield positive results, a verification test should be performed. If both screening tests and the verification test yield positive results, HIV infection can be diagnosed (since the serum contains HIV-specific antibodies) [1].

Establishment of a correct diagnosis in cases of newborns, infants and children exposed to HIV-1 infection is difficult since HIV-specific antibodies penetrate through placenta to foetal blood, in which they may persist for a long time [3]. Therefore, serological tests in children below 18 months of life may be falsely positive and cannot be considered the final, definitive and confirming test. 
Thus, diagnosis of HIV infection in children below 18 months of life should be based on tests directly detecting presence of the virus or its components (e.g. HIV RNA, HIV DNA or a very sensitive test for presence of p24 antigen) confirmed by another virological test on a sample obtained from independent blood sampling at the time more than 4 weeks after birth [4].

Every woman who is pregnant or plans pregnancy should be tested for HIV. In countries such as Great Britain, France or the Netherlands, the tests are performed in around $98 \%$ of pregnant women, in Poland, they cover slightly less than $10 \%$ of pregnant women only [5].

Medical personnel's knowledge of biology of motherto-child HIV transmission is also an important factor [6] HIV infection is frequently accompanied by other STI (sexual transmitted infections) such a $C$. trachomatis infection, which may be transmitted vertically $[7,8]$.

An HIV-infected pregnant woman should be subjected to control of HIV viral load in blood $(\mathrm{VL})$ and of the number of CD4+ cells in blood three times during pregnancy with the last tests performed in the $36^{\text {th }}$ week of pregnancy. In cases when the woman became infected by a partner infected with a drug-resistant strain, the treatment proves to be insufficient or ineffective, drug resistance of the virus should be examined [5].

A very sensitive method for detection of HIV presence was found to involve PCR (polymerase chain reaction), a test capable of detecting even very low amounts of nucleic acids. If in the $48^{\text {th }} \mathrm{h}$ of newborn's life the test yields a positive result (pointing to presence of the pathogen) the infection took place inside the uterus, when the result of the test is negative in the $48^{\text {th }} \mathrm{h}$ but positive between the $7^{\text {th }}$ and $90^{\text {th }}$ day the infection developed most probably during delivery [9].

Cytometric measurement of lymphocytes T CD4+ and of lymphocytes T CD8+ numbers is of a key importance for the patient's prognosis and for the decision on ART implementation. In line with current recommendations, patients with a number of lymphocytes T CD4(+) $<350 / \mu \mathrm{l}$ should undergo antiretroviral treatment [10].

Recent studies demonstrated that the total number of lymphocytes CD4(+) achieved following application of HAART is markedly dependent on both lymphocytes $T$ number determined as soon as possible following seroconversion (the so-called baseline CD4 level) and the lowest lymphocyte $T$ level noted in the patient anytime in the past (the so-called CD4 nadir). Moreover, the baseline CD4 remains directly related to the post-HAART number of lymphocytes CD4, independently of the other prognostically significant variables (e.g. CD4 nadir). In other words, the more lymphocytes are contained in the patient's blood at the moment of seroconversion, the more favourable is his/her prognosis. The quoted reports imply that the baseline CD4 level is of a prognostically important significance for a patient's therapy [11].

Management of an $\mathrm{HIV}(+)$ pregnant woman depends mainly on her blood lymphocyte CD4+ number and on the degree of clinical advancement. The management was specified by WHO recommendations [4] (Table 1).

\section{Legal and medical aspects of HIV infection and AIDS diagnosis}

Due to their specificity, problems linked to infection with HIV and with acquired immune deficiency syndrome (AIDS) are not simple and continue to pose several difficulties of a legal and medical type for physicians. Most of the doubts are related to problems associated with the patient's rights to autonomy and to definition of secrecy limits related to results of performed studies. Problems of the patient's rights form a significant portion of medical law and within recent years were subject to several alterations, updates and modifications. Every physician who provides health care is obliged to know rights of patients while related ignorance or behaviour violating the legal rules exposes the physician to penal, civil or professional liability [17-20].

Isolation of a blood sample from a patient and its testing for presence of HIV infection results in encroachment into the patient's privacy area, which is legally protected by various regulations.

Under the principal act, the Constitution of the Republic of Poland of 2 April 1997 (Journal of Laws No. 78, item 483, as amended) every citizen has right to have his health protected (Art. 68.1), and also has a guaranteed right to self-estimation, privacy and decisions related to his/her fate (Art. 41 "Personal inviolability and security shall be ensured to everyone.") [21].

The problem is also regulated by the Penal Code in its Art. 192: "whoever performs a therapeutic procedure with no consent of the patient will be liable to a penalty of a fine, restriction of freedom or imprisonment". Also the Code of Medical Ethics in its Art. 15 indicates that "a diagnostic, therapeutic and preventive procedure requires consent of the patient" [22, 23].

Furthermore, the Act on Patients' Rights and on Advocate for Patients' Rights provides that the patient has the right to have his/her intimacy and dignity respected, to express his/her consent to provision of specified healthcare services and refuse such consent following obtaining information on his/her health condition. A medical procedure performed in the absence of patient's consent or when the consent is improper, even if the procedure was performed correctly from the medical point of view, represents an illegal action. Patient's consent can be revoked at any time before the start of the medical procedure. The above legal acts belong to the patient's autonomy [24].

Analysis of legal regulations indicates that the diagnosis of HIV infection can be established only upon patient's consent. A visit to a physician's office cannot be and is not equivalent to patient's acceptance of a suggested diagnosis and treatment. The patient admitted to 
a hospital upon preliminary examination in the admission office affixes his/her signature in the history of a disease, concluded with the following statement: "I agree to the treatment and operative procedure suggested to me". Such an agreement of the patient, the so-called formal consent, represents no agreement to the operative procedure or respective examination procedures of a higher than average risk. Patient's consent provided upon admission to a hospital does not cover subsequent procedures.

Blood sampling for examination of anti-HIV antibodies fails to pose a direct risk to the patient's health but, due to the specific type of the diagnosis, it should not be covered by the general consent of the patient before examination and treatment [25-30].

The principal normative rules related to management in cases of suspicion of or diagnosis of infection with HIV are provided in the Act on Prevention and Combating Infections and Infectious Diseases in Humans of 5 December 2008 (Journal of Laws No. 234, item 1570), the Act on Patients' Rights and Advocate for Patients' Rights of 6 November 2008 (Journal of Laws of 2009 No. 52, item 17), and the Council of Ministers' regulation of 15 February 2011 on the National Programme for Prevention against HIV Infections and Combating AIDS [24, 31, 32].

\section{Diagnosis}

In the diagnosis of infection with HIV, two categories of tests are distinguished: compulsory tests, voluntary tests.

\section{Compulsory diagnostic tests}

Such tests are performed regardless of the patient's consent or even against the patient's will. Such tests are conducted in cases of prevention and combating of infectious diseases. Infections with human immunodeficiency virus (HIV) and the acquired immunodeficiency syndrome (AIDS) were classified as infections and infectious diseases within legal meaning with all its consequences. The tests are controlled by the Act of Prevention and Combating Infections and Infectious Diseases in Humans of 5 December 2008 [31].

In the discussed respect, its Art. 5.1 is of a decisive significance as it stipulates that individuals staying in the Republic of Poland are obliged to undergo sanitary/epidemiological tests, including procedures aimed at sampling or securing material for such tests.

In line with Art. 6 of that Act, individuals obliged to undergo sanitary/epidemiological tests include:

- Individuals suspected of being infected/infecting with an infectious disease (HIV or AIDS; an individual suspected of AIDS is a person manifesting clinical signs/symptoms or deviations from a normal condition in laboratory studies which may indicate AIDS; an individual suspected of being infected is a person who does not manifest signs/symptoms of HIV infection or AIDS but who had contact with a source of infection and the type of infectious agent or circumstances of the contact justify the suspicion of the infection);

- Newborns, infants and pregnant women, suspected of infection or an infectious disease (HIV or AIDS), which might spread from mother to her foetus or a child;

- Carriers, convalescents and persons who were exposed to infection due to their contact with infected individuals, AIDS patients or the infectious material. In the above-mentioned cases, the individuals are referred for tests by a regional state sanitary inspector, appropriate for the place of stay of the individual to be tested;

- Pupils, students and PhD students trained to perform occupations with the potential for transmission of HIV infection or AIDS to other persons. They are referred for such tests by a director/vice-chancellor of the school or a person authorized by him/her;

- Persons undertaking or performing work with a potential for passing HIV infection or AIDS to other persons. Such persons are referred for tests by their employer or principal.

Art. 33 of the Act indicates that in cases of suspected HIV infection or AIDS, a state regional sanitary inspector may order, by an administrative decision, immediate performance of compulsory testing etc. of the suspected individual or person in whom the infection or the disease has been diagnosed, as specified by Art. 5 .

Blood donors who voluntarily donate blood, even in the absence of their clear consent to blood sampling for purposes of diagnosis of HIV infection, are also tested for HIV infection. In order to voluntarily donate blood, a person has to be healthy, which is linked to systematic testing $[26,27]$.

Newborns of mothers who did not undergo HIV tests in the course of their pregnancy due to their refusal, are tested for HIV after informing the mother about it. Such a testing is treated as a routine procedure, similarly as e.g. in phenylketonuria. The procedure follows the recommendation of the Polish Gynaecological Society related to prevention of HIV perinatal transmission of 24 October 2008 [5].

Regulations of penal law provide for situations in which obligatory tests can be performed. In a penal process, a defendant, as specified in Art. 74 of the Code of Penal Proceedings, is obliged to undergo psychological and psychiatric examinations and examinations linked to performance of procedures on his/her body except for surgery. Nevertheless, if performance of such studies is indispensable, the procedures have to be conducted by a qualified health care employee with preservation of indications specified by medical knowledge and they cannot endanger health of the defendant. Specifically, upon preservation of such conditions, the defendant is obliged to submit to blood sampling. In specific cases, the procedures can be performed under duress [22]. 
Table 1. Criteria of evaluation of HIV infection/AIDS advancement according to WHO, modified on the basis of WHA recommendations [12]

\begin{tabular}{|c|c|c|}
\hline $\begin{array}{l}\text { Degree of clinical advancement } \\
\text { according to WHO }\end{array}$ & Clinical signs/symptoms & Remarks \\
\hline \multirow{2}{*}{$\begin{array}{l}\text { 1. Degree of clinical advancement } \\
\text { according to WHO }\end{array}$} & Asymptomatic patient & Absence of signs suggesting HIV infection in physical examination \\
\hline & $\begin{array}{l}\text { Persisting generalized } \\
\text { lymphadenopathy }\end{array}$ & $\begin{array}{l}\text { Painless enlarged lymph nodes ( }>1 \mathrm{~cm} \text { in diameter) in two distant } \\
\text { sites (other than inguinal lymph nodes) with no detectable cause } \\
\text { persisting for at least } 3 \text { months }\end{array}$ \\
\hline \multirow[t]{8}{*}{$\begin{array}{l}\text { 2. Degree of clinical advancement } \\
\text { according to WHO }\end{array}$} & $\begin{array}{l}\text { Moderate unexplained } \\
\text { loss of body weight by } 10 \%\end{array}$ & $\begin{array}{l}\text { Detected unexplained loss of body weight and inability to increase } \\
\text { it during pregnancy }\end{array}$ \\
\hline & $\begin{array}{l}\text { Recurrent bacterial } \\
\text { infections in upper } \\
\text { respiratory pathways } \\
\text { (the event manifested now } \\
\text { plus one or more during } \\
\text { recent } 6 \text { months) }\end{array}$ & $\begin{array}{l}\text { Variable symptomatology: rhinorrhoea with unilateral facial } \\
\text { pain (sinusitis), primary otalgy (otitis media), pharyngitis and } \\
\text { tonsillitis with no signs of viral infection (such as cough or rhinitis) }\end{array}$ \\
\hline & $\begin{array}{l}\text { Herpes zoster (re-infection } \\
\text { with VZV, Varicella zoster } \\
\text { virus) }\end{array}$ & $\begin{array}{l}\text { Painful vesicular eruption restricted to dermatome supplied } \\
\text { by a single nerve, it does not cross midline of the body }\end{array}$ \\
\hline & $\begin{array}{l}\text { Angular stomatitis } \\
\text { (lip sores) }\end{array}$ & $\begin{array}{l}\text { Skin cracks in angles of the mouth not linked to deficiency of iron } \\
\text { or vitamins, usually reacting to antifungal treatment [13] }\end{array}$ \\
\hline & $\begin{array}{l}\text { Regressing ulcerations in } \\
\text { the oral cavity ( } 2 \text { or more } \\
\text { episodes within recent } \\
6 \text { months) }\end{array}$ & $\begin{array}{l}\text { Aphthous ulcerations, painful, with a typical inflamed halo } \\
\text { and yellow-green pseudomembrane }\end{array}$ \\
\hline & Pruritic papular eruption & $\begin{array}{l}\text { Papular lesions accompanied by pruritus, frequently with } \\
\text { postinflammatory discoloration }\end{array}$ \\
\hline & Seborrhoeic dermatitis & $\begin{array}{l}\text { Pruritic dermal eruption of uneven surface, located within hairy } \\
\text { skin (skin of the head, in axillae, upper part of trunk, inguinal regions) } \\
\text { [14] }\end{array}$ \\
\hline & Fungal infection of nails & $\begin{array}{l}\text { Painful, red, enlarged nail bed - paronychia. } \\
\text { Separation of the nail plate from its bed - onycholysis (white } \\
\text { discoloration, affecting in particular proximal parts of nail plates } \\
\text { with its thickening and separation of the plate from its bed) [15] }\end{array}$ \\
\hline \multirow[t]{3}{*}{$\begin{array}{l}\text { 3. Degree of clinical } \\
\text { advancement acc. to WHO }\end{array}$} & $\begin{array}{l}\text { A pronounced, unexplained } \\
\text { loss of weight (over } 10 \% \\
\text { of body weight) }\end{array}$ & $\begin{array}{l}\text { The above loss of weight with evident slimming of face, trunk } \\
\text { and extremities, with cachexia or BMI below } 18.5 \mathrm{~kg} / \mathrm{m}^{2} \text {. } \\
\text { In pregnancy, loss of body weight may be hidden }\end{array}$ \\
\hline & $\begin{array}{l}\text { Diarrhoea of unexplained } \\
\text { aetiology lasting for more } \\
\text { than } 1 \text { month }\end{array}$ & $\begin{array}{l}\text { Chronic diarrhoea ( } 3 \text { or more loose or watery stools per day) } \\
\text { noted for more than } 1 \text { month [16] }\end{array}$ \\
\hline & $\begin{array}{l}\text { Continuous or relapsing } \\
\text { unexplained fever persisting } \\
\text { for at least } 1 \text { month }\end{array}$ & $\begin{array}{l}\text { Fever, nocturnal sweats persisting for more than } 1 \text { month, relapsing } \\
\text { or continuous, with noted lack of reaction to treatment with } \\
\text { antibiotics and anti-malaria agents, with no evident focus } \\
\text { of infection upon physical examination. In regions affected } \\
\text { by malaria it should be excluded to diagnose fever of unexplained } \\
\text { aetiology }\end{array}$ \\
\hline
\end{tabular}


Table 1. cont.

\begin{tabular}{|c|c|c|}
\hline $\begin{array}{l}\text { Degree of clinical advancement } \\
\text { according to WHO }\end{array}$ & Clinical signs/symptoms & Remarks \\
\hline & $\begin{array}{l}\text { Blastomycosis of the } \\
\text { oral cavity }\end{array}$ & $\begin{array}{l}\text { Persisting or relapsing créme-coloured pseudomembranous scales } \\
\text { (which could be scraped off upon examination) or red spots } \\
\text { on the tongue, palate, oral mucosa, usually painful and sensitive } \\
\text { (erythematous form) }\end{array}$ \\
\hline & $\begin{array}{l}\text { Leukoplakia in mucosa } \\
\text { of the oral cavity }\end{array}$ & $\begin{array}{l}\text { Fine, white linear lesions on lateral tongue margins, which cannot } \\
\text { be scraped off }\end{array}$ \\
\hline & Pulmonary tuberculosis & $\begin{array}{l}\text { Chronic signs/symptoms (persisting for at least 2-3 weeks): cough, } \\
\text { bloody sputum, dyspnoea, pain in the chest, loss of body weight, } \\
\text { night sweats, fever + a positive result of microbiological testing } \\
\text { of saliva for presence of tuberculous bacilli or a negative result } \\
\text { of such test with X-ray examination confirming tuberculosis } \\
\text { (including involvement of upper pulmonary lobes, pulmonary } \\
\text { fibrosis and an decrease in lung volume, formation of cavities, } \\
\text { the lesions may be more widespread). Lack of proof for } \\
\text { involvement of extrapulmonary tissues }\end{array}$ \\
\hline & $\begin{array}{l}\text { Acute bacterial infections } \\
\text { (e.g. pneumonia, meningitis, } \\
\text { empyema, purulent myositis, } \\
\text { infections of bones } \\
\text { and joints, bacteraemia, } \\
\text { PID - syndrome of } \\
\text { inflammation in organs } \\
\text { of small pelvis) }\end{array}$ & $\begin{array}{l}\text { Fever accompanied by local signs, symptoms and their alleviation } \\
\text { following introduction of an appropriate antibiotic therapy }\end{array}$ \\
\hline & $\begin{array}{l}\text { Acute, necrotic, ulcerative } \\
\text { inflammation of the oral } \\
\text { cavity, gingiva or } \\
\text { periodontium (the so called } \\
\text { Plaut-Vincent's angina) }\end{array}$ & $\begin{array}{l}\text { Acute pain, ulcerations of interdental papillae, pathological } \\
\text { movement of teeth, spontaneous bleeding, foul smell from } \\
\text { mouth, rapid loss of osseous tissue and/or soft tissues }\end{array}$ \\
\hline & $\begin{array}{l}\text { Unexplained anaemia } \\
(\mathrm{HB}<8 \mathrm{~g} / \mathrm{dl}) \text {, neutropoenia } \\
\text { (neutrophils number } \\
<0.5 \times 109 / \mathrm{l}) \text { and/or chronic } \\
\text { (persisting for at least } \\
\text { a month) thrombocytopenia } \\
\text { (number of platelets } 50 \times 109 /\end{array}$ & Diagnosis established on the basis of laboratory tests on blood \\
\hline $\begin{array}{l}\text { 4. Degree of clinical } \\
\text { advancement acc. to WHO }\end{array}$ & HIV wasting syndrome & $\begin{array}{l}\text { Documented loss of weight (above } 10 \% \text { of body weight) with visible } \\
\text { cachexia and patient's BMI not exceeding the value of } 18.5 \mathrm{~kg} / \mathrm{m}^{2} \\
\text { or } \\
\text { Unexplained chronic diarrhoea (loose or watery stools eliminated } \\
\text { at least thrice a day) persisting for more than } 1 \text { month } \\
\text { or } \\
\text { Episodes of fever or nocturnal sweats appearing for more than } \\
1 \text { month with no other reason than HIV infection and not reacting } \\
\text { to treatment with antibiotics and anti-malaria drugs. In regions with } \\
\text { manifestation of malaria, this disease should be excluded before HIV } \\
\text { infection-linked exhaustion syndrome can be diagnosed }\end{array}$ \\
\hline
\end{tabular}


Table 1. cont.

\begin{tabular}{|c|c|c|}
\hline $\begin{array}{l}\text { Degree of clinical advancement } \\
\text { according to WHO }\end{array}$ & Clinical signs/symptoms & Remarks \\
\hline & $\begin{array}{l}\text { Pneumocystosis - } \\
\text { pneumonia induced } \\
\text { by Pneumocystis jiroveci }\end{array}$ & $\begin{array}{l}\text { Exertional dyspnoea or dry cough, which appeared within the last } \\
3 \text { months; tachypnoe and fever } \\
\text { and } \\
\text { lung radiogram confirming a widespread, bilateral interstitial } \\
\text { infiltration } \\
\text { and } \\
\text { lack of evidence pointing to bacterial pneumonia. } \\
\text { During auscultation bilateral cracks over both lungs } \\
\text { with/without obturation }\end{array}$ \\
\hline & $\begin{array}{l}\text { Relapsing bacterial } \\
\text { pneumonia (current event } \\
\text { plus one or more such } \\
\text { infections within the } \\
\text { recent } 6 \text { months) }\end{array}$ & $\begin{array}{l}\text { Acute beginning of such a disease, lasting less than } 2 \text { weeks, in which } \\
\text { fever, cough, dyspnoea and pain in the chest appear) } \\
+ \\
\text { Development of new adhesions seen in chest radiograms. } \\
\text { The infection responds to treatment with antibiotics }\end{array}$ \\
\hline & $\begin{array}{l}\text { Chronic infection with } \\
\text { Herpes simplex virus } \\
\text { (oral-labial; anorectal } \\
\text { or genital) persisting for } \\
\text { at least } 1 \text { month or any } \\
\text { visceral infection with } \\
\text { H. simplex independently } \\
\text { of the infection's duration }\end{array}$ & $\begin{array}{l}\text { Painful, progressing anogenital ulceration, or such an ulceration } \\
\text { of oral cavity mucosa or lips. Lesions induced by relapsing infection } \\
\text { with } H \text {. simplex virus, manifested for at least } 1 \text { month. } \\
\text { In anamnesis relapsing episodes of herpetic infections. Herpetic } \\
\text { lesions of inner organs require further diagnostic efforts }\end{array}$ \\
\hline & $\begin{array}{l}\text { Blastomycosis of } \\
\text { oesophagus (candidiasis) }\end{array}$ & $\begin{array}{l}\text { Recent development of retrosternal pains and problems with } \\
\text { swallowing (food and drinks) associated with blastomycosis } \\
\text { of the oral cavity }\end{array}$ \\
\hline & $\begin{array}{l}\text { Extrapulmonary } \\
\text { tuberculosis }\end{array}$ & $\begin{array}{l}\text { Systemic disease (fever, nocturnal sweats, weakening and loss of } \\
\text { body weight). Extrapulmonary or disseminated tuberculosis may } \\
\text { manifest by lesions located in pleura, pericardium, peritoneum, } \\
\text { cerebrospinal meninges, mediastinum; it may be accompanied } \\
\text { by lymphadenopathy of mediastinal and abdominal lymph nodes, } \\
\text { osteitis. } \\
\text { Miliary tuberculosis: it is uniformly disseminated in the form of small } \\
\text { miliary shadows noted on radiograms } \\
\text { Infection with tuberculous bacilli of cervical lymph nodes may be } \\
\text { treated as a milder form of extrapulmonary tuberculosis }\end{array}$ \\
\hline & Kaposi's sarcoma & $\begin{array}{l}\text { Typical localization involves skin or oral portion of pharynx } \\
\text { (oropharynx). Persisting at the beginning flat spots of dermal lesions, } \\
\text { with a pink or purple colour which used to form scales or nodules } \\
\text { of a violet colour }\end{array}$ \\
\hline & $\begin{array}{l}\text { Toxoplasmosis of the } \\
\text { central nervous system }\end{array}$ & $\begin{array}{l}\text { Recent appearance of a focus of neurological disturbances } \\
\text { or a lowered level of awareness and response to an appropriate } \\
\text { treatment within } 10 \text { days }\end{array}$ \\
\hline & $\begin{array}{l}\text { Progressive multifocal } \\
\text { leukoencephalopathy (PML) }\end{array}$ & $\begin{array}{l}\text { Progressive neurological disturbances: (cognitive disturbances, } \\
\text { disturbed gait, speech, narrowing of visual field, weak extremities, } \\
\text { paralysis of cranial nerves) linked to demonstration of lesions } \\
\text { of white matter in neuroimaging studies or a positive result of PCR } \\
\text { test on JC polyomavirus, the etiological agent of PML presence, } \\
\text { in the cerebrospinal fluid }\end{array}$ \\
\hline
\end{tabular}


Table 1. cont.

\begin{tabular}{|c|c|c|}
\hline $\begin{array}{l}\text { Degree of clinical advancement } \\
\text { according to WHO }\end{array}$ & Clinical signs/symptoms & Remarks \\
\hline & $\begin{array}{l}\text { Infection with a cytomegaly } \\
\text { virus or CMV infection } \\
\text { in other organs, except liver, } \\
\text { spleen and lymph nodes) }\end{array}$ & $\begin{array}{l}\text { The diagnosis established on the basis of isolated retinitis can be } \\
\text { concluded only by experienced clinicians. The typical lesions noted } \\
\text { upon examination of fundus of the eye involve clearly outline white } \\
\text { spots in retina spreading centripetally, frequently along blood } \\
\text { vessels, linked to reticular vasculitis, haemorrhage and necrosis }\end{array}$ \\
\hline & $\begin{array}{l}\text { Extrapulmonary } \\
\text { cryptococcosis (including } \\
\text { cerebrospinal meningitis } \\
\text { of this aetiology) }\end{array}$ & $\begin{array}{l}\text { Meningitis: usually of a subacute character, fever with increasingly } \\
\text { pronounced headache, meningeal reaction, patient's disorientation, } \\
\text { altered behaviour; the disease responds to anticryptococcal } \\
\text { treatment. Definitive diagnosis results from isolation of Cryptococcus } \\
\text { neoformans from a sample of extrapulmonary tissues or a positive } \\
\text { result of tests for presence of CRAG infection linked antigen } \\
\text { in blood or cerebrospinal fluid }\end{array}$ \\
\hline & $\begin{array}{l}\text { Disseminated } \\
\text { mycobacteriosis }\end{array}$ & $\begin{array}{l}\text { The diagnosis is based on detection of atypical bacilli in microscope } \\
\text { examination of faeces, blood, body fluid samples or samples of other } \\
\text { tissues other than samples isolated from lungs }\end{array}$ \\
\hline & $\begin{array}{l}\text { Encephalopathy in the course } \\
\text { of HIV infection/AIDS }\end{array}$ & $\begin{array}{l}\text { Diagnosis of cognitive disturbances and/or motor disturbances } \\
\text { linked to basic functions, progressing within weeks or months upon } \\
\text { absence of diseases/events other than HIV infection which might } \\
\text { explain the above mentioned signs/symptoms. The diagnosis can be } \\
\text { established following exclusion of other potential causes; } \\
\text { if possible, neuroimaging should be performed (computer-assisted } \\
\text { tomography or magnetic resonance tomography) }\end{array}$ \\
\hline & $\begin{array}{l}\text { Cryptosporidiosis } \\
\text { (with a diarrhoea persisting } \\
\text { for at least } 1 \text { month) }\end{array}$ & $\begin{array}{l}\text { In cases of manifestation of the disease cysts of Cryptosporidium } \\
\text { can be identified in preparations of unformed faeces isolated from } \\
\text { the patient and stained according to Ziehl-Neelsen }\end{array}$ \\
\hline & Chronic isosporiasis & $\begin{array}{l}\text { Isospora belli should be identified in a sample isolated from the } \\
\text { patient to confirm infestation with the parasite }\end{array}$ \\
\hline & $\begin{array}{l}\text { Wide spread fungal } \\
\text { infections (coccidiomycosis, } \\
\text { histoplasmosis) }\end{array}$ & $\begin{array}{l}\text { Histological examination, detection of antigens or preparation } \\
\text { of appropriate cultures of respective samples or blood }\end{array}$ \\
\hline
\end{tabular}

Recurrent episodes of sepsis Final diagnosis can be established by culture

(including sepsis induced of blood samples

by non-typhoid salmonellosis)

Primary cerebral lymphoma Diagnosis is established by histopathological examination or non-Hodgkin B-cell of an appropriate sample and, in cases of tumours

lymphoma or other solid in the central nervous system on the basis of neuroimaging tumours linked to HIV infection

\begin{tabular}{ll}
$\begin{array}{l}\text { Invasive uterine cervix } \\
\text { carcinoma }\end{array}$ & $\begin{array}{l}\text { Definite diagnosis is obtained on the basis of histopathological } \\
\text { or cytological examination }\end{array}$ \\
\hline $\begin{array}{l}\text { Atypical wide spread } \\
\text { leishmaniasis }\end{array}$ & $\begin{array}{l}\text { Histological examination demonstrating Leishmania amastigotes } \\
\text { and/or culture of samples obtained from the patient }\end{array}$ \\
\hline $\begin{array}{l}\text { Nephropathy in the course } \\
\text { of HIV infection/AIDS }\end{array}$ & Final diagnosis can be obtained by performing renal biopsy \\
$\begin{array}{l}\text { Cardiomyopathy in the } \\
\text { course of HIV } \\
\text { infection/AIDS }\end{array}$ & $\begin{array}{l}\text { The diagnosis requires demonstration of cardiomegaly and proving } \\
\text { of restricted left ventricular ejection fraction, confirmed } \\
\text { by echocardiography }\end{array}$
\end{tabular}


Persons sentenced basing on the Executive Penal Code can be subjected to compulsory testing. Art. 116 of the Code contains the order for a defendant to submit to the tests, treatment, medical and sanitary procedures and rehabilitation specified by regulations, regardless of obligations defined by norms related to combating infectious, venereal diseases, tuberculosis, alcoholism and drug abuse.

The obligation to submit to such studies is also specified in the Code of Petty Offences. In the light of law, an offence includes also refusal to provide explanation related to an (infectious) disease, failure to submit to protective vaccination or obligatory examination (Art. 115.1 of the Executive Penal Code: "...those who fail to undergo compulsory examination of his/her health condition...") [33].

\section{Voluntary diagnostic tests}

Blood tests for the purposes of diagnosis of HIV infection can be conducted on request of the patient. Such tests are performed and data on HIV infection are protected by professional secrecy. The patient is entitled also to have blood tested anonymously. According to the law, the voluntary diagnosis of HIV infection takes place when the following conditions are fulfilled:

- blood sampling and the test were performed upon consent of the authorized person,

- the consent was given in an evident manner,

- the patient agreed to the test after being informed about the purpose and character of the test or when a presumptive consent can be assumed.

If the above mentioned conditions are not fulfilled and the patient has requested that a doctor establish cause(s) of his/her complaints, particularly clinical signs/symptoms typical of an infectious disease, protozoan infection, viral infection including HIV, the diagnosis is legal and consent can be surmised as implied consent.

Basing on the same principles, blood can be sampled for needs of HIV infection diagnosis in the case when a patient reported to a doctor for full check-up examinations of his/her health condition of a preventive character. In either situation, the patient did not refuse but also did not agree to blood sampling for purposes of HIV infection diagnosis.

Apart from the cases of voluntary and obligatory studies, HIV infection diagnosis can be performed when such an action is secret to the examined person (without permission) or even when the examined person is wilfully misinformed (erroneous consent). Such situations have no legal basis and, thus, they should be treated as wilful blood sampling by a doctor for the purpose of testing the blood for presence of anti-HIV antibodies without patient's awareness of this secrecy or following misinforming the patient or fully openly when the patient cannot object to it because the blood has already been drawn.
In cases of tests directed to HIV infection diagnosis involving blood samples taken legally earlier for other purposes and stored in the lab, rules of penal law do not apply since the blood has already been legally drawn earlier upon consent of the patient.

In some cases, performance of secret diagnostic tests for HIV will not result in legal responsibility of the physician if such tests are conducted in order to protect third parties in a state of necessity (Art. 26 of the Penal Code), specifying that endangered values can be saved at the cost of sacrificing another value. Art. 26.1 of the Penal Code can be applied when health and life of other persons present a higher value than rights to self-determination, freedom and immunity of the tested individual. In a state of necessity we are posed with a conflict of values since blood sampling and performance of HIV diagnostic tests against the patient's will in the well based medical interest, e.g. protection of third parties (medical staff) against infection from the patient violates personal rights of the patient [22].

This takes place in a situation when a direct risk endangers health of a person in whose interest the test was supposed to be performed but the risk could not have been omitted in any other way, e.g. to protect medical staff from becoming infected.

The direct nature of HIV infection risk to third parties is fulfilled when specific situations arise. In such situations, the requirement of undertaking immediate rescue measures is of a principal significance. The physician is confronted with an alternative: to take actions or to tolerate the imminent danger. The direct risk to health and life of third parties, despite ignorance as to seropositivity of the individual who might represent the source of risk, can be concluded when:

1. Implications exist pointing to a potential HIV infection in a patient who is supposed to be subjected to involuntary and not obligatory tests (e.g. manifesting signs/symptoms typical of AIDS-linked opportunistic infections);

2. A real potential exists for getting infected from the examined individual by third parties, e.g. during operation with violation of skin continuity the medical staff is exposed to such a risk.

The state of necessity may also develop when activities have been undertaken to eliminate risks for health and life of the tested individual. In such situations, e.g. the following circumstances argue for performing diagnosis of HIV infection:

- the fact that upon earlier detection of HIV infection, therapeutic measures can be applied which slow down development of the disease and the earlier the infection is diagnosed, the higher are chances for making the carrier's life longer; 
- detection of seropositivity allows to apply other security measures, e.g. isolation;

- in the infected individual, surgery and therapeutic methods not indicated in the carriers may be given up.

According to some authors, referring to the state of necessity upon compulsory drawing patient's blood is intolerable and violates the law. This view can be approved from the point of view of sensibility and, on the other hand, it would violate the patient's right to self-determination [25-29].

\section{References}

1. Diagnosis, prophylaxis, clinic and therapy of HIV infections/AIDS: contemporary potential and problems [Polish]. Gładysz A, Knysz B (eds.). Continuo, Wrocław 2009.

2. Mikulska M, Grabarczyk P, Brojer E, et al. Diagnosis of infectious agents transmitted with blood [Polish]. JTM 2008; $1 ; 1-19$.

3. Buchholz B, Hien S, Weichert S, et al. Pediatric aspects of HIV1-infection: an overview. Minerva Pediatr 2010; 62: 371-87.

4. WHO. WHO case definitions of HIV for Surveillance and revised clinical staging and immunological classification of HIVrelated disease in adults and children. 2007. www.who.int/ hiv/pub/guidelines/HIVstaging150307.pdf

5. Recommendations of the team of experts for prevention against neonatal transmission of HIV of 20th October, 2008, Polish Gynaecological Society (in Polish). Ginekol Pol 2009; 80: 59-62.

6. Rogowska-Szadkowska D, Pentkowska E, Chlabicz S. The risk of vertical transmission of HIV- the knowledge of gynaecologists and midwives. Ginekol Pol 2008; 79: 862-6.

7. Łącka K, Żaba R, Zachwieja A, et al. Hormonal contraception and risk of sexually transmitted disease acquisition. Postep Derm Alergol 2011; 28: 302-8.

8. Chojnacka K, Szczapa J, Kędzia W. Częstość perinatalnej transmisji Chlamydia trachomatis i powikłania z nią związane u noworodków przedwcześnie urodzonych. Ginekol Pol 2012; 83: 116-21.

9. Simonds RJ, Steketee R, Nesheim S, et al. Impact of zidovudine use on risk and risk factors for perinatal transmission of HIV. AIDS 1998; 12: 301-8.

10. Cambiano V, Rodger AJ, Phillips AN. 'Test-and-treat': the end of the HIV epidemic? Curr Opin Infect Dis 2011; 24: 19-26.

11. Kulkarni H, Okulicz JF, Grandits G, et al. Early post-seroconversion CD4 cell counts independently predict CD4 cell count recovery in HIV-1-postive subjects receiving antiretroviral therapy. J Acquir Immune Defic Syndr 2011; 57: 387-95.

12. World Health Organization, Antiretroviral therapy for HIV infection in adults and adolescents (2010 revision). 2010 http://whqlibdoc.who.int/publications/2010/9789241599764 eng.pdf.

13. Rosińska-Więckowicz A, Misterska M, Bartoszak L, et al. Cheilitis - case study and literature review. Postep Derm Alergol 2011; 28: 231-9.

14. Błaszkowski M, Kaczorowska A, Staszek D, et al. Dermatoza o obrazie klinicznym przypominającym łojotokowe zapalenie skóry. Postep Derm Alergol 2010; 27: 101-5.

15. Gniadek A, Skóra M, Garlicki A, et al. Prevalence of dermatophytes in interdigital spaces in HIV patients. Postep Derm Alergol 2012; 29: 30-4.
16. Chmiel K, Krela-Kaźmierczak I, Łykowska-Szuber L, et al. Association between dermatological diseases and pathological changes in the gastrointestinal tract. Postep Derm Alergol 2011; 28: 506-13.

17. Jakubowicz J, Jakubowicz O Żaba C, et al. Legal problems linked to infection with HIV virus and AIDS [Polish]. Postep Derm Alergol 2009; 26: 150-4.

18. Boratyńska M, Konieczniak P. Rights of the patient [Polish]. Difin, Warszawa 2001.

19. Żaba C, Żaba Z, Klimberg A, Świderski P. Diagnosis of HIV infection in the light of legal regulations [Polish]. Arch Med Sąd Krym 2007; 57: 118-21.

20. Jakubowicz J, Jakubowicz O, Żaba C, et al. Lekarz - funkcjonariusz publiczny? Postep Derm Alergol 2010; 27: 119-21.

21. Constitution of the Republic of Poland [Polish]. Journal of Laws 1997; 78, item 483.

22. Penal Code [Polish]. Journal of Laws 1997; 88, item 553 as amended.

23. Code of Medical Ethics of 2 January 2004 [Polish] as amended.

24. Act of 6 November 2008 on Patients' Rights and Advocate for Patients' Rights [Polish]. Journal of Laws 2009; 52 item 17.

25. Grajewski J, Paprzycki LK, Steinborn S. Code of penal proceeding. Comments [Polish], 2006; I: art. 1-424.

26. Kubicki L. Medical law [Polish]. Urban \& Partner, Wrocław 2003, 44-8.

27. Nesterowicz M. Medical law [Polish]. Toruń 2004.

28. Pigulska W. Diagnosis of HIV infections and penal law [Polish]. Wydawnictwo Poznańskie, Poznań 1998.

29. Sandorski J. Claiming of rights of HIV-positive/AIDS patients [Polish]. Wydawnictwo Poznańskie, Poznań 2003.

30. Stachowiak S. Penal process problems linked to HIV/AIDS [Polish]. Wydawnictwo Poznańskie, Poznań 2001.

31. Act on Prevention and Combating Infections and Infectious Diseases in Humans of 5 December 2008. Journal of Laws 2008; 234, item 1570.

32. Council of Ministers' Regulation of 15 February 2011 on the National Programme of Preventing HIV Infections and Combating AIDS [Polish].

33. Code of Petty Offences [Polish]. Journal of Laws 1971; 12: item 114, as amended. 